\title{
ENTREPRENEURIAL CULTURE OF KUBE
}

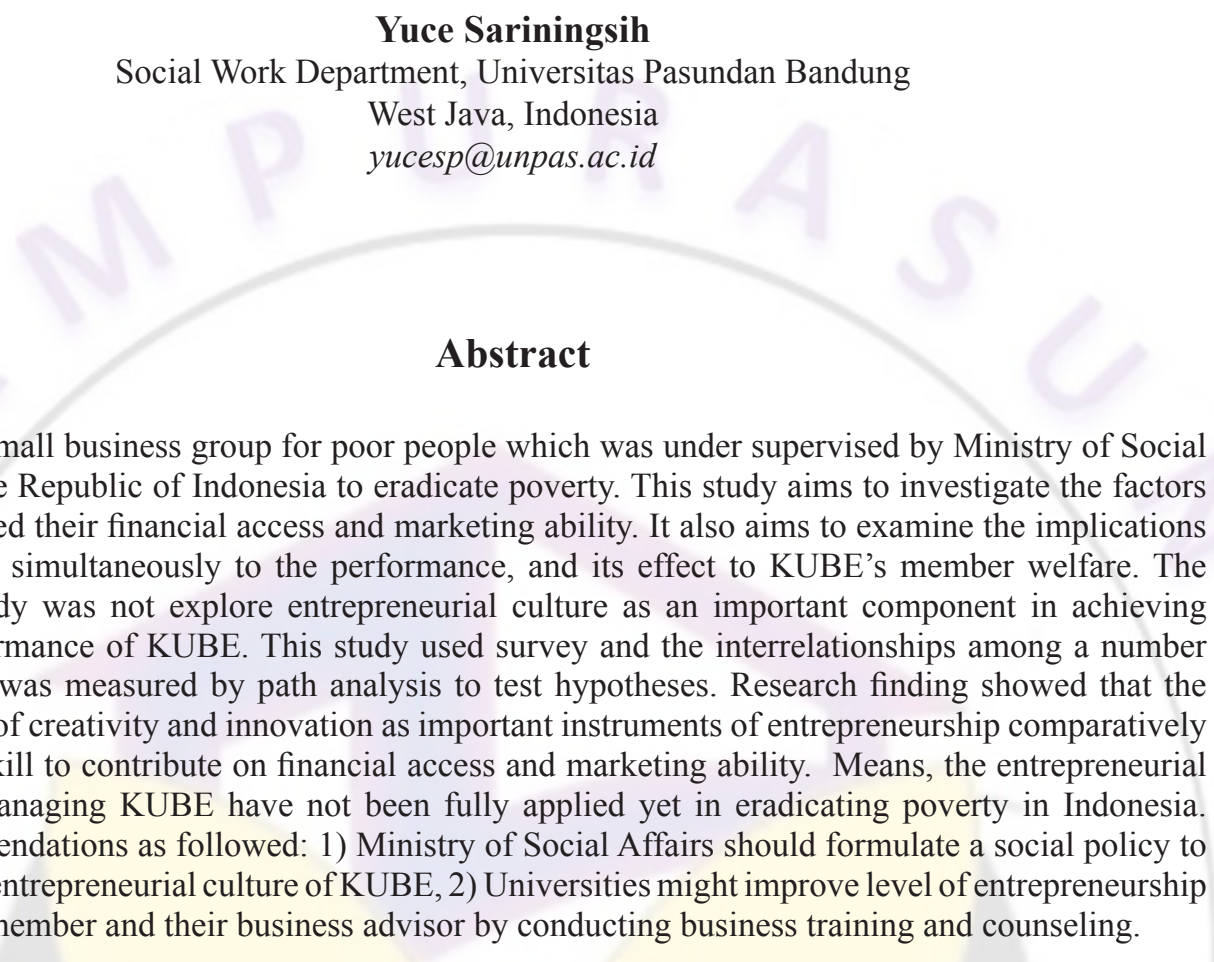

KUBE is a small business group for poor people which was under supervised by Ministry of Social Affairs of the Republic of Indonesia to eradicate poverty. This study aims to investigate the factors that influenced their financial access and marketing ability. It also aims to examine the implications partially and simultaneously to the performance, and its effect to KUBE's member welfare. The previous study was not explore entrepreneurial culture as an important component in achieving higher performance of KUBE. This study used survey and the interrelationships among a number of variables was measured by path analysis to test hypotheses. Research finding showed that the direct effect of creativity and innovation as important instruments of entrepreneurship comparatively small than skill to contribute on financial access and marketing ability. Means, the entrepreneurial culture in managing KUBE have not been fully applied yet in eradicating poverty in Indonesia. The recommendations as followed: 1) Ministry of Social Affairs should formulate a social policy to strenghthen entrepreneurial culture of KUBE, 2) Universities might improve level of entrepreneurship of KUBE's member and their business advisor by conducting business training and counseling.

Keywords: entrepreneurship, financial access, marketing ability and welfare.

\section{Introduction}

Poverty in Indonesia is still quite high based on Indonesian Statistical Bureau (2015), it was about 28 million of the total 17 million occurred in the countryside. This means that approximately $60.71 \%$ of poverty occurs in rural areas, these conditions become a problem with the lower welfare status of rural communities. The entrepreneurial spirit to be one of the core instruments for the individual in carrying out efforts to raise up the people's economy level, which aimed to alleviate poverty in Indonesia as a result of the prolonged economic crisis. Entrepreneurship can be an important indicator of whether or not a country reflected their economic profile, however, entrepreneurship which consist of creativity and innovation as well as fighting spirit and endurance in carrying out small businesses is still not yet popular by most people in Indonesia.
The skills that are related to the improvement of competence of the task is often not realized by people although they were very motivated to work (Winardi, 2007). These condition as a reason of the Ministry of Social Affairs at the national level to address poverty by giving some grant to the poor women who joined in small business group for improving economic activities problem by forming KUBE. The grant was IDR. 20.000.000,- equal with around USD 1300 for each group that consisted of 10 person.

Innovation in small business is not remarkable findings, but a discovery that led to use economic resources more productive (Alma, 2008). The term innovations in KUBE is not extraordinary innovation of the appearance of a product. Low levels of creativity, innovation and skill in using economic resources are the cause of failure of small and medium enterprises like KUBE. 
The problem experienced by small business group that similar with KUBE were the weaknesses in the areas of financial access (Machfoedz, 2004), are as follows:

1. The problem in seeking skilled employees; Small and medium companies may be able to provide high salaries but can not provide other warranties such as large corporations. Small and medium business do not have employee development program and promotion are very limited. This leads to loss the opportunity for the company to recruit well-qualified employees.

2. The difficulty of the capital increase; Persons who provide capital is very limited. Unlike large companies, small independent traders are not able to collect a large amount of capital. Expected cash flow may be sufficient for daily operations, but when will expand the business may be difficult to obtain capital, and the cause of the failure of such entrepreneurs is the lack of knowledge and management experience.

The performance of KUBE in running a small business have also been considered not yet optimal, have not actually been able to run a small business they started. Things turn off of KUBE do not usually associated with a lack of money (Bustami, 2007), talent or information but more related to something more fundamental, that were low level of entrepreneurship spirit and understanding of business management.

The failure of the small business is often triggered by weak marketing efforts (Zimmerer et. al., 2005), where eople talk about entrepreneurs as a risk takers (Hughes, 2002). On the contrary, good entrepreneurs are masterful at identifying risk and developing a plan to manage and offset risk. The stronger the leader, the more risk the individual is capable assuming, and the more responsibility that individual must marshal to creatively manage the risk Creativity and innovation are the core of entrepreneurship.

KUBE was expected to improve the socioeconomic conditions of the lower strata of society to improve living standards, as well as able to cope social unrest caused by the helplessness and instability economy.
Creative thinking and innovative has been the core business skills, and entrepreneur become a leader in the effort to develop and apply these skills. Creativity and innovation are also the criteria for social assistance activities in the implementation of business group work so that members are expected to have the creativity and innovation are also high.

Every business group work has a distinctive and specific characteristics (General Guidelines for KUBE: 2004), both of resources, customs, values and the habits. Therefore, in addition to social welfare should be able to explore the potential for harnessing KUBE to be a source of empowerment, should also be able to develop creativity and innovation in order to improve the ability of members of KUBE in recognizing and utilizing potentials.

KUBE should have the ability to apply creative solutions to problems and opportunities to improve or enrich the lives of people. Innovation and creativity are the main functions in the entrepreneurial process. Entrepreneurs can combine imaginative and creative mind with the ability of a logical and systematic process. Potential entrepreneurs are always looking for a unique opportunity to meet the needs and desires.

Creativity and innovation are two important concepts (Wirasasmita, 2008), where innovation is a process of changing, experimenting, transforming and revolutionizing (Coulter, 2000). A business group work must develop an entrepreneurial culture as a culture that is open to new technology transfer into products and business activities. Business group work must be flexible, able to accept change and be willing to accept failure as the path to success.

Business has felt the need to create new products (DeGraff and Lawrence, 2002), Without these new ideas, economic, technological, and social progress would be slow indeed. Management includes planning, organizing, leading, and controlling of human activities (George et. al.; 2006). Innovation as the management resources is the specific instrument of entrepreneurship to get an economic value (Drucker, 1985). It is the act that endows resources with a new capacity to create wealth. Innovation, indeed 
creates resources and does not have to be technical, does not indeed have to be a "thing" altogether.

Change and innovation are passionate processes. Successfully planned change requires a commitment grounded in an engaging vision and deep emotional involvement with the program. An efforts to address the creativity and innovation is by strengthening the entrepreneurial mentoring, access to capital and product marketing. The concept of team building counterpart in the implementation of productive economic activities through connecting KUBE in the context of Intellectuals, Business and Government (IBG) to improve the creativity, innovation and skills KUBE. Productive business activities through KUBE is one of the activities to achieve the community welfare.

Very worthy of mention the issue of minority and women-owned businesses in developing country. The more generic issue was the gender problem, the marginalization of women entrepreneurs was regarded as commonplace. However, in recent times, increasing the sensitivity of policy makers was witnessed for women entrepreneur. There are also nongeneric issues such as culture and values of some Asia Pacific economies which come in the way of women entrepreneurship development.

Indonesia currently has only $0.18 \%$ of entrepreneurs (entrepreneurs) of the population. In fact, the developed countries should have at least $2 \%$ of the population engaged in the entrepreneurial sector (http: //wikipedia.web.id, 2009). Indonesia needs at least 4.07 million entrepreneurs or two percent of the population to support optimal growth. There must be at least 4.07 million entrepreneurs in Indonesia (Halim in http:// m.antaranews.com (2009).

Indonesia shows a figure lower than the percentage of the population that was selfemployed. Hasan (in http://kompas.web.id, 2009), which stated: "The percentage of the population in Singapore of self-employed reached 7 percent, China and Japan reached 10 percent, while the highest is the United States amounted to 11.5 to 12 percent. Entrepreneurship population.
The Smal Medium Enterprise in the Philippines has had consistent themes in terms of management structure, market orientation, type of labor, sourcing inputs, a source of capital and source of technology. (Ndubisi, 2008). Generally, the most problem faced by small scale industry cannot compete in low-end markets with the lower labor cost competitor.

\section{Method}

The study employed explanatory survey method and the data source was primary and secondary data. A Questionnaire, observation, and structured interview have been chosen for the data gathering techniques. Data has been analyzed by path analysis, which simply used the words "cause" and "effect" as statistical terms similar to independent variables, or exogenous and endogenous variables.

This study has been conducted in West JavaIndonesia for 8 (eight) months at KUBE women in the district of Bandung, Majalengka, Kuningan, Cirebon. Garut, Ciamis, Banjar in West Java. Some considered as a pilot project KUBE program with significant result according to Social Affairs Board of West Java Province, 2009).

\subsection{Population and Sampling}

The unit of analysis in this study was KUBE for poor Women who received business assistance in form of money and goods for the development of their business activities. The research population was the entire poor women who joined in 46 groups, consisted of 450 beneficiaries. Samples were taken by using Proportional Cluster Sampling from the population group of poor women business group as beneficiaries of KUBE aid who got money (amount with 900 USD/group/10 women) or goods.

Sampling was chosen by using Multistage Cluster Sampling. The first stage in taking a sample group was determined $80 \%$ of the 46 groups as population equal with 36.8 or 37 groups consisting of 360 beneficiaries KUBE as described in the following Table 1. 
Table 1. A Sample of KUBE for Poor Women at West Java

\begin{tabular}{|c|c|c|c|}
\hline Location & Address (Sub-District) & Kind of Business & Member \\
\hline \multirow[t]{10}{*}{ Bandung Regency } & 1. Ciparay & Bag Craftsmen & 10 \\
\hline & 2. Ciparay & Bag Craftsmen & 10 \\
\hline & 3. Margahayu & Food vendors & 10 \\
\hline & 4. Katapang. & Tailor & 10 \\
\hline & 5. Katapang. & Tailor & 5 \\
\hline & 6. Katapang. & Food seller & 10 \\
\hline & 7. Pacet. & Daily product & 10 \\
\hline & 8. Pacet. & Bag Craftsmen & 10 \\
\hline & 9. Kutawaringin. & Food seller & 5 \\
\hline & 10. Cileunyi & Food seller & 10 \\
\hline \multirow[t]{5}{*}{ Majalengka Regency } & 1. Maja. & Crackers & 10 \\
\hline & 2. Maja & Crackers & 10 \\
\hline & 3. Dawuan & Sheep farmer & 10 \\
\hline & 4. Dawuan & Sheep farmer & 10 \\
\hline & 5. Dawuan & Sheep farmer & 10 \\
\hline \multirow[t]{10}{*}{ Garut Regency } & 1. Kersamanah. & Crackers & 10 \\
\hline & 2. Garut & Batik & 10 \\
\hline & 3. Karangpawitan. & Craft & 10 \\
\hline & 4. Karangpawitan. & Craft & 10 \\
\hline & 5. Banyuresmi & Crackers & 10 \\
\hline & 6. Banyuresmi & Noodle & 10 \\
\hline & 7. Banyuresmi & Crackers & 10 \\
\hline & 8. Garut & Cake & 10 \\
\hline & 9. Garut Kota & Crackers & 10 \\
\hline & 10. Kota & Coconut sugar & 10 \\
\hline \multirow[t]{3}{*}{ Kuningan Regency } & 1. Kadugede & Sheep farmer & 10 \\
\hline & 2. Kadugede & Daily product & 10 \\
\hline & 3. Kadugede & Salon & 10 \\
\hline \multirow[t]{3}{*}{ Ciamis Regency } & 1. Cidolog & Tailor & 10 \\
\hline & 2. Cidolog & Embroidery & 10 \\
\hline & 3. Cidolog & Embroidery & 10 \\
\hline \multirow[t]{3}{*}{ Banjar City } & 1. Langensari & Sheep farmer & 10 \\
\hline & 2. Langensari & Dried banana & 10 \\
\hline & 3. Langensari & Dried banana & 10 \\
\hline \multirow[t]{3}{*}{ Cirebon City } & 1. Lemahwungkuk & Daily product & 10 \\
\hline & 2. Lemahwungkuk & Daily product & 10 \\
\hline & 3. Lemahwungkuk & Daily product & 10 \\
\hline Total & & 37 Groups & 360 \\
\hline
\end{tabular}

Sumber: Social Affairs Board, West Java Province, 2008. 
The second stage was to take 3 respondents from each group purposively according to the following criteria:

1. A part of the group with the position as chairman, or secretary or treasurer of the business groups.

2. Registered in Social Affairs Board as a beneficiary of money or good and still running some business.

Based on those criteria, then drawn a number of samples that represented a group as the third stage, that was 37 groups multiple 3 respondents equal with 111 respondents.

\subsection{Resarch Instruments}

The data gathering used a questionnaire to the poor women who joined in KUBE as respondents, then record their answer. The question for the measurement instrument employed a close ended or multiple choice, questions asked the respondent to choose an answer from a list of alternative. The scaling used a Likert scale that was a semantic differential where respondents were asked to choose between opposite poles on an issue (Morris, 2016)

Testing the validity of the data used the product moment correlation coefficient and reliability testing technique used in this research was Cronbach Alpha technique. This study used a series of calculation and then decided whether can or not reject the null hypothesis at a predetermined level of $5 \%$.

\section{Results And Discussion}

West Java Province - Indonesia located in western Java is bounded by the province of Central Java (Jawa Tengah) to the east, the Indian Ocean to the south, the province of Banten to the west, the capital district of Jakarta to the northwest, and the Java Sea to the north. The capital of West Java is Bandung. The principal means of livelihood in Central Java is agriculture; rice, tobacco, sugarcane, corn (maize), rubber, tea, coffee, cinchona bark, sweet potatoes, and fruits and vegetables are grown or collected. Industries produce textiles, ceramics, footwear, tires, electric bulbs, processed food, beverages, nonmetallic mineral products, transport equipment, and paper. There are also printing, shipbuilding, and automobile-assembly plants.

Chairman of the Indonesian Chamber of Commerce and Industry (Kadin) of West Java, Agung Suryamal Sutisno revealed West Java Kadin has implemented GARUDA program, Entrepreneurial Movement village. This movement as an attempt of Kadin creating entrepreneurs in rural areas. (jabarprov.go.id/ En/.../West Java Kadin Held GARUDA Program). GARUDA program inspired by the Chinese State who at 25 years or 30 years ago, where the citizen at that time become a burden. But now the economy and development in China developed rapidly. This economic and development progress because of China could be able to empower the population of 1.3 billion citizens to be productive. GARUDA program was launched at Cililin, West Bandung regency. Cililin was chosen because this is the center of female Indonesian migrant workers (TKW). West Java Kadin supported by Bank BRI in giving the train to the TKW in this area.

\subsection{KUBE: A Recent Policy Initiative}

Poverty is the basis for economically productive activities grant program through the Business Group (KUBE). Addressing poverty requires cooperation, support, and synergy of all stakeholders, including local government sector, civil society, and the business world, so the intertwined unity of movement steps to jointly improve the ability of the poor to access sources of material, intellectual and information optimally. Definition and scope of poor women business group (KUBE) according to the Ministry of Social Affairs of the Republic of Indonesia are as follows:

1. Business Group (KUBE) is a group of citizens or socially assisted family formed by citizens or socially assisted family that has been fostered through the process of Social Welfare Program (PROKESOS) to carry out activities of social welfare and economic efforts in the spirit of togetherness as a means to improve social welfare.

2. KUBE an integrated approach and the overall process of implementation of the Social Welfare Program (PROKESOS). 
KUBE formation begins with the process of group formation as a result of social assistance, business skills training, assistance and mentoring stimulant. At the provincial level, productive business through Business Group (KUBE) organized by the Social Service Department of West Java Province. Referring to the Guidelines for the Implementation and Technical Guidelines, Guidance Business Productive Economic for Women Prone Socioeconomic, West Java Provincial Government, Department of Social Welfare (2008) stated that: "KUBE is a community empowerment in national economic development, which in the future is expected to be embryo SMEs and stimulate the economy with social welfare issues ". One type of KUBE KUBE is a woman, based on consideration for women as the economic backbone of the family

Most small business owners do marketing moves direct to every customer that encountered in the effort that some of the prospective buyers would be interested. This approach can no longer be used when the business is growing. poor women business group expected to develop their entrepreneurial spirit to promote small business they started, as well as being an innovator is able to utilize and transform opportunities into ideas that can be sold or marketed, adds value by leveraging the effort, time, cost or skills in order to gain profit. Therefore, it is necessary to increase the managerial ability to organize productive economic activities, to develop operational capabilities, obtain funds for venture capital and manage business activities. In addition, it is necessary to increase the technical knowledge to realize ideas, thus expected to combine creative thinking and imaginative capabilities logical and systematic process, which is key to the success of this fusion productive economic activities.

Productive business can expand marginalized communities to access capital slightest, such access has a transformative effect on human lives. Over time, many people with limited ability of capital were able to use a small capital loan as the basis to build a lasting, in the form of a plot of agricultural land, farms, food industry, craft workshops or small shop, which can be lifted out of poverty. Access to capital can ultimately increase the incomes of the poor. Goals and objectives of the activities organized by the Business Group (KUBE) refer to the Guidelines and Technical Guidance, Social Services West Java (2008), as follows:

1. Enhancing capability in fulfilling the needs and improvement of social welfare of members.

2. Enhancing KUBE members in addressing the problems that occur in the family and social environment.

3. Improving the ability of members of KUBE in displaying his social role.

While the targets KUBE program is a group of poor families or certain people who will get help Social Guidance and Skills, Productive Economic Enterprises aid stimulant intended for:

1. KUBE for Needy Families

2. KUBE for Vulnerable Families

3. KUBE for Poor Women

4. KUBE for Juvenile

5. KUBE with Disabilities

6. KUBE for Neglected Children

7. KUBE for the Elderly

8. KUBE for Youth

9. KUBE for Orphan

10. Communication Forum Community Social Worker.

The productive business developed covering the fields of agriculture, animal husbandry, fisheries, forestry, household industry, services and other economic activities. The activities carried out in the form of venture capital assistance in the form of economic infrastructure and the benefits of living channeled directly or through the mechanism of banking. The establishment and development of a KUBE implemented within five (5) stages:

1. Preparation; The activities in the preparatory phase consists of orientation and observation, registration and identification, planning, program implementation, general social counseling, guidance problem recognition, motivation and evaluation guidance preparation (which is done by the village officials, officers, and supervisors functional companion).

2. Implementation Phase; The activities during the implementation phase 
includes the selection of candidates for Families Patronage Social (KBS), the establishment of pre-group and group selection / determination of the type of business, training companion, skills training members of KUBE, life insurance, assistance stimulant capital, mentoring and evaluation (conducted by village officials, escort officers, supervisors functional and relevant agencies).

3. The phase of Business Development; The activities at this stage of business development covers business development guidance, provision of business development assistance, mentoring and evaluation (conducted by officers' escort and clerk functional builder).

4. Stage Business Partnership; The activities at this stage include an inventory of the resources that exist (natural resources, economic resources, social resources and human resources), making agreements execution of business partnerships, expansion of the network of business partnerships and evaluation (conducted by the mentor and adviser functional).

5. Monitoring and Evaluation Phase; the activities at this stage include process control and monitoring ongoing implementation and evaluation of the success that has been achieved (implemented by escort officers and supervisors functional).

Target activities through the Productive Economic Business Guidance for WRSE KUBE are women with the criteria and requirements as follows:

A. Criteria:

1. Age 17-50 years;

2. Widows as a head of household or live alone;

3. Women who became head of the household;

4. Women as the main breadwinner in the family (wife whose husband left indefinitely, and or pain that can not work for a living);

5. Income less or do not meet the minimum physical needs;

6. The education level is low (usually a maximum of completion of primary education).
B. Requirements

1. Based in the village designated as the location of activities;

2. Physically and mentally healthy;

3. Classified women who have low incomes, believe it is less than Rp. 96521 , - per person / month for rural areas, and Rp. 130 499, - per person / month for urban areas. (Susenas BPS and Social Affairs, 2002).

4. Have expertise and skills in the Productive Economic Business (UEP) which allows developed technically and operationally.

5. Never fostered by the Social Welfare Program, implemented by both Social Agency of West Java and West Java Provincial Office of Social Ministry.

6. Interested, honest, willing to cooperate in activities Productive Economic Enterprises for Fiscal Year 2008 WRSE.

7. Willing to manage relief efforts in the form of Productive Economic Enterprises in KUBE.

KUBE institutional structure depending on the type of business you run, so there is no standard structure, yet simple organizational structure that can be used as a reference refers to the Guidelines for the Implementation and Technical Guidance, Social Services Provincial Government of West Java (2008) consisted of:

1. Chairman

2. Secretary

3. Treasurer

\subsection{Creativity and Innovation of KUBE}

The variables in this study were creativity (X1), innovation (X2), skill (X3), financial access (Y1), marketing ability (Y2), performance (Z1) and welfare level (Z2). Explanation took the form of a causal statements models that incorporate these variables, that is, the variables of creativity (X1), innovation (X2), skill (X3) caused variables of financial access (Y1) and marketing ability (Y2). Then, variables of financial access (Y1) and marketing ability (Y2) caused performance (Z1) as an intervening variable. The outcome of this research that performance (Z1) caused welfare level (Z2) of poor women business group who joined in KUBE (Table 2.). 
Tabel 2. Result of Direct Effect and Indirect Effect

\begin{tabular}{|c|c|c|c|}
\hline Variabler & Direct Effect & Indirect Effect & Total Effect \\
\hline Variable $X_{1}$ to $Y_{1}$ & $12.600 \%$ & $15.100 \%$ & $27.700 \%$ \\
\hline Variable $\mathrm{X}_{2}$ to $\mathrm{Y}_{1}$ & $5.900 \%$ & $8.900 \%$ & $14.800 \%$ \\
\hline Variable $X_{3}$ to $Y_{1}$ & $17.100 \%$ & $11.000 \%$ & $28.100 \%$ \\
\hline Other variable & & & $29.400 \%$ \\
\hline Total & & & $100.000 \%$ \\
\hline Variable $X_{1}$ to $Y_{2}$ & $12.600 \%$ & $13.500 \%$ & $26.100 \%$ \\
\hline Variable $\mathrm{X}_{2}$ to $\mathrm{Y}_{2}$ & $4.600 \%$ & $11.300 \%$ & $15.900 \%$ \\
\hline Variable $\mathrm{X}_{3}$ to $\mathrm{Y}_{2}$ & $13.800 \%$ & $13.200 \%$ & $27.000 \%$ \\
\hline Other variable & & & $31.000 \%$ \\
\hline Total & & & $100.000 \%$ \\
\hline Variable $Y_{1}$ to $Z_{1}$ & $20.000 \%$ & $13.900 \%$ & $33.900 \%$ \\
\hline Variable $Y_{2}$ to $Z_{1}$ & $23.500 \%$ & $13.900 \%$ & $37.400 \%$ \\
\hline Other variable & & & $28.700 \%$ \\
\hline Total & & & $100.000 \%$ \\
\hline Variable $Z_{1}$ to $Z_{2}$ & $74.300 \%$ & & $74.300 \%$ \\
\hline Other variable effect & & & $25.700 \%$ \\
\hline Total & & & $100.000 \%$ \\
\hline
\end{tabular}

Source: Research finding, August 2010.

The result of a hypothesis also known as a test of significance can be interpreted on several levels. One hypothesis called the null hypothesis, denoted $\mathrm{H} 0$ is very specific and claimed that the mean is equal to a definite specific value. The other hypothesis denoted $\mathrm{H} 1$, and claim that the mean was some other value than the hypothesized value (Siegel and Morgan, 1996). The result of testing this hyphotesis based on a sample of data was that one of them will be accepted and the other rejected. To test the effect of independent variable partially used t-table for $95 \%$ critical values with the degrees of freedom was n-k1. To test the effect of independent variable simultaneously used $\mathrm{F}$ table with $5 \%$ critical value. The result of testing hypothesis as followed (Table 3.)

The above data showed that the variable skill has the greatest influence on the financial access, followed by creativity variable that has a strong enough influence on financial access. While the influence of the smallest variable to financial access variable was innovation.

Hypothesis testing results indicated that creativity, innovation, and skillssimultaneously and partially significant and positive impact on the financial access. Partially, skill variable most significance effect on the financial access, and then creativity and innovation. In general, respondents had to have technical skills accordance with its business, as this skill becomes one component of the assessment process of the Ministry of Social Affairs when considering them as beneficiaries so that the respondents received help economically productive activities. Respondents already have business skills but remain limited on financial access and marketing. While creativity and innovation 
Tabel 3. The Result of Hypothesis Test

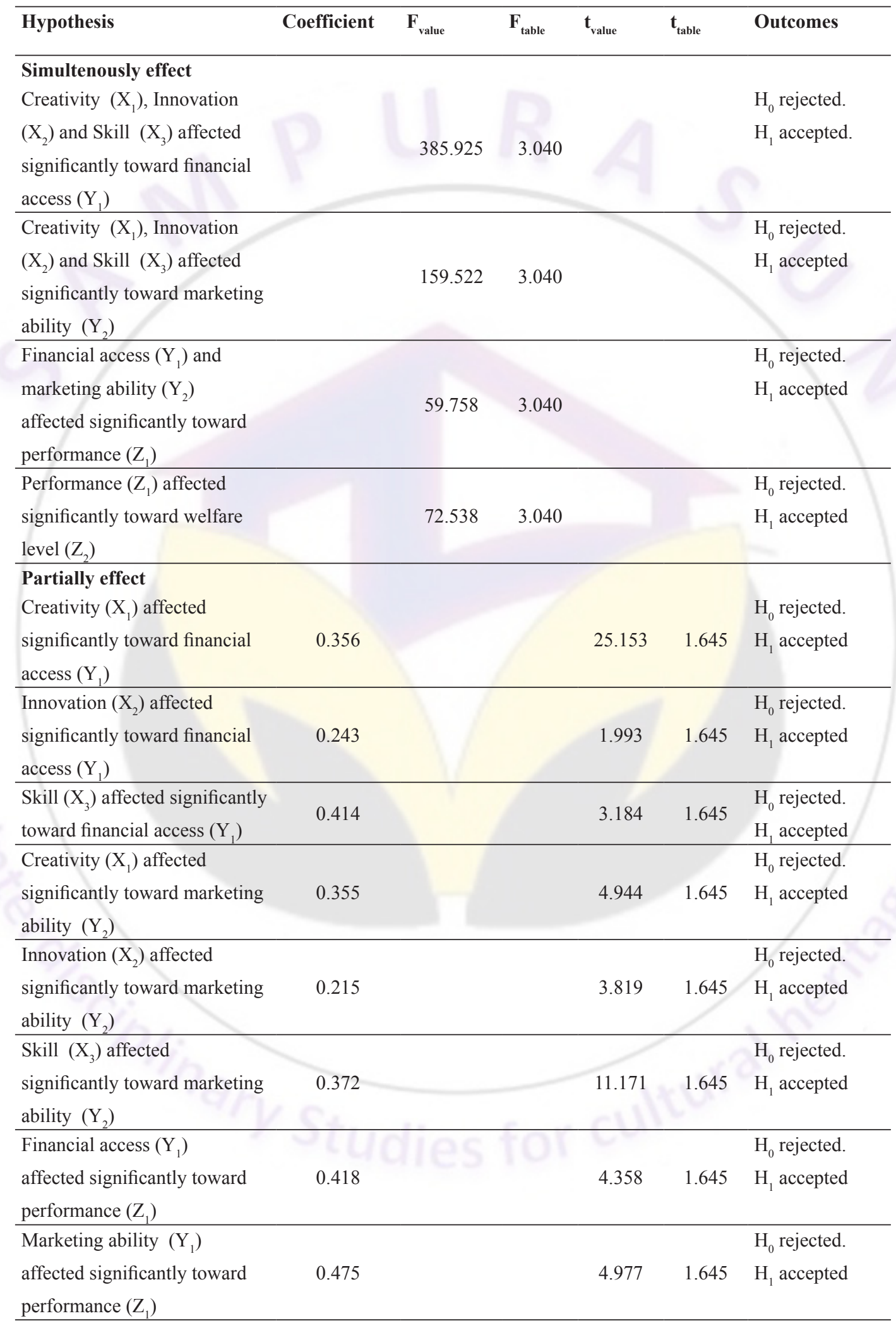

Source: Research finding, August 2010 
Creativity is a new idea, whereas innovation is the commercialization or application of new ideas Wirasasmita (2008: 5). Creativity and innovation are actually related to each other and are indispensable in improving financial access and marketing ability. Respondents as an entrepreneur must continually emerge the way of creativity. Level rapid changes have created an environment that required creativity and innovation in order to remain in position. Thus creative solutions are needed to improve the financial access to carry out the business.

The financial statements of small businesses as a form of creativity is needed to achieve the simple goal, which is to evaluate the performance and planning tools business and access to funds from financial institutions, particularly banks to develop the business (Golrida, 2008: 1). However, most respondents have not yet implemented this simple recording properly, so creativity is emerging for small business development would be meaningless without embodied in an action, in the form of simple bookkeeping administered.

Respondents had the great idea to increase financial access but have not had the courage to apply for a bank loan, because of unpreparedness at risk if it is unable to pay the mortgage. Nonetheless, respondents are interested in forming a cooperative and borrow money from the savings and loan activities carried out by the cooperative. Creativity has not been able to be realized in the form of innovation, which is in this study can be regarded as a level of respondent's ability to utilize the resources available to realize creative ideas. Furthermore, as an innovation, KUBE is expected to be the embryo of small businesses and cooperatives, where respondents have a high entrepreneurial spirit. As an entrepreneur, respondents should encourage the realization of creativity that is called innovation in doing business. One reason that could be a latent variable of the problem in realizing entrepreneurship to eradicate poverty in Indonesia is culture. As mentioned above, the KUBE member would not take a risk to propose some loan from the bank, this is one kind of culture. On the other hand, culture is an important part of the entrepreneurial environment. To encourage more entrepreneurs, a country needs a set of beliefs that make entrepreneurship a valid and respected career choice.

The development of an entrepreneurial culture implies their mental attitude to come forward as much as possible in carrying out productive economic activities. The importance of entrepreneurial strategies to anticipate the negative impact of social assistance to beneficiaries, in order to avoid dependence on a continuous basis, or realize that the aid received is a stimulant of venture capital, which is, in turn, should be able to be developed on the basis of its own strength or potential joint business group (General Guidelines for KUBE, 2004). True entrepreneurs generated creativity and innovation relentlessly, so it can be said that the core of the entrepreneur is the creativity and innovation.

The entrepreneur needed an ability to perform a particular task, both physically and mentally (Meoheriono, 2009). Creativity and innovation are also related to the skills where entrepreneurs are expected to emerge from the economic activity through productive economic activities are expected as an entrepreneur who has the skills, especially entrepreneurs who have the power of entrepreneurial skills. Skills are an important component in the development of the business, in line with it can be said that the level of skills of an entrepreneur affected the successful on increasing the financial access and marketing. Skills possessed by the respondent at the time of technical skill alone was likely to produce a product. These skills must be developed constantly and go into a loop.

The creative industries are industries that rely on elements of talents, skills, and creativity. These three elements are a fundamental element of the individual so that everyone has a basic capital equal and free (Moelyono, 2010). By optimizing the utilization of the creative potential of these three elements, then means it has participated in the efforts to increase the capacity building of Indonesian human resources.

The creativity that generated innovation is often associated with the mastery of high technology. It is the old paradigm. Innovation could also not of technology but of new value 
generated. Innovation can be achieved by the creation of new value that can be created by micro enterprises, though. Development with a capital of creativity that is focused and effective, in the long term will be able to increase growth and equity (growth and equity), so as to improve the quality of life (well-being) through community empowerment. KUBE women can be regarded as one of the creative industries are the kinds of products are not much different from that produced by Small Medium Enterprise (SME) but has not been fully supported by the banks. As the creative industry is very responsive to absorb the accumulation of social phenomena in society and poured into context in the form of products and services such as fashion apparel products and crafts and entertainment products, agriculture and animal husbandry.

To develop the creative economy in Indonesia, the concept of the actor is very important, they are scholars (intellectuals), business (business) and the government (government), or the abbreviated IBG. Referring to the above opinion, to achieve the ability of capital in accordance with the indicators KUBE, then the respondent should be assisted by a team of a business counselor who will assist theKUBE member to emerge creativity, innovation, and skills. The business counselor team also must understand the interaction between scholars, business, and government to improve the financial access and marketing ability.

These three components interact in a system greatly affect creativity, innovation and skills of respondents in improving the ability of capital. Strengthening the business counselor team in enhancing creativity, innovation, and skills of respondents in carrying out productive economic activities is very important, it is also on the consideration that the respondents have low education levels and as the economic backbone of the family. The team basically as a motivator and provide insights on entrepreneurship and skills training, which consisted of voluntary who has a knowledge in business and representatives of universities/ academics (realize a variety of activities related to management, helping to make the design of the loan application of venture capital and establish relationships with banks facilitator in the formation of cooperatives, to establish business networks with business partners, facilitate access to funding populist economic development of Corporate Social Responsibility (CSR), and other activities related to the acceleration of capital), and other relevant experts if necessary.

\section{Conclusion}

Business Group (KUBE) under supervised by Ministry of Social Affair Republic of Indonesia is a group of citizens or socially assisted family formed by citizens or socially assisted family, that has been fostered through the process of Social Welfare Program (PROKESOS) to carry out activities of social welfare and economic efforts in the spirit of togetherness as a means to improve social welfare. KUBE program aims to tackle poverty through community empowerment by moving the local economic potential to the society itself, in synergy with the existence of cooperatives to development capital, the expected outcome is the impact the welfare of the surrounding community.

Creativity and innovation are the core of entrepreneurship, and creativity has a close connection with innovation. Poor women business group was expected to improve the socio-economic conditions for the lower strata of society to improve living standards, as well as well able to cope with social unrest caused by the helplessness and inability economy.

Hypothesis testing results indicated that creativity, innovation, andskillssimultaneously and partially significant and positive impact on the financial access. Partially, skill variable most significance effect on the financial access, and then creativity and innovation. In general, respondents had to have technical skills accordance with its business, as this skill becomes one component of the assessment process of the Ministry of Social Affairs when considering them as beneficiaries so that the respondents received help economically productive activities. Respondents already have business skills but remain limited on financial access and marketing. While creativity and innovation among respondents generally still weak.

The application of entrepreneurship culture in managing KUBE as small businesses 
has not been fully applied yet in addressing the problem of poverty in Indonesia. The KUBE member would not take a risk to propose some loan from the bank, this is one kind of culture which has been some barrier in business developing. On the other hand, culture is an important part of the entrepreneurial environment. To encourage more entrepreneurs, a country needs a set of beliefs that make entrepreneurship a valid and respected career choice. A voluntary business counselor is very crucial for KUBE business development in order to facilitate among Intelectual parties, Business dan Government. The recommendation of this study was directed to Academic Community, Business Sector and Government (Ministry of Social Affairs Republic of Indonesia) as followed:

1. Ministry of Social as government representative should improve their entrepreneurship culture by conducting business training for KUBE member and voluntary business advisor.

2. Universities as representative of academic community should carry out a research and community service related to improve entrepreneurship of KUBE

3. Business sector should develop a program based on Corporate Social Responsibility Program for helping KUBE's management.

\section{References}

Afiff, Faisal. Dr., 1982. Strategi Pemasaran. Bandung: Angkasa.

Alma, Buchari., Prof., Dr., 2008. Kewirausahaan. Bandung: Alfabeta.

Anwar, Dr., MPd., Manajemen Pemberdayaan Perempuan (Perubahan Sosial Melalui Pembelajaran Vocational Skill pada Keluarga Nelayan). Bandung: Alfabeta.

Bustami et.al. 2007. Mari Membangun Usaha Mandiri. Yogyakarta: Graha Ilmu.

Chun Li, Ching. 1975. Path Analysis, a Primer. New York: The Boxwood Press.

Costa, Joana et.al. 2008. The Burden of Gender Inequalities for Society. Number 13, (January 2008), International Poverty Centre
Coulter, Mary. 2000. Entrepreneurship in Action. New Jersey: Upper Saddle River, Prentice Hall.

Creswell, John W. 1994. Research Design, Qualitiative and Quantitative Approaches. California: Sage Publication.

DeGraff, Jeff \& Lawrence, Katherie A. Creativity at Work,Developing the Right Practices to Make Innovation Happen. San Francisco: John Wiley \& Sons. Inc.

Dermawan Wibisono. 2006. Manajemen Kinerja. Konsep, Desain dan Teknik Meningkatkan Daya Saing Perusahaan. Jakarta: Erlangga.

Dinas Sosial Pemerintah Propinsi Jawa Barat. 2008. Pedoman Pelaksanaan dan Petunjuk Teknis, Kegiatan Bimbingan Usaha Ekonomi Produktif bagi Wanita Rawan Sosial Ekonomi, Tahun Anggaran 2008. Bandung: Dinas Sosial Pemerintah Propinsi Jawa Barat.

Drucker. Peter F. 1985. Innovation and Entrepreneurship, Practice and Principles. New York: Harper \& Row Publisher.

Formula Bisnisnet. 2009. Kemandirian Pengelolaan KUBE. Jakarta: www. formulabisnisnet.com.

Gordon, Judith R et.al. 1990. Management and Organizational Behavior. Massachusetts: Simon \& Schuster., Inc.

Hasan, Dr Syarief. (Menteri Koperasi dan UKM). 2009. Jumlah Wirausahawan di Indonesia. Surabaya: www.kompas.com. [1 Februari 2010].

Halim,NeddyRafinaldi.2009.Kewirausahaan. Jakarta: Deputi Bidang SDM Kementerian Koperasi dan UKM, http://m.antaranews. com. [3 Maret 2009].

Hughes, Alice (ed.). 2002. The Entrepreneurial Problem Solver. New York: Aspatore Books., Inc.

Indonesian Statistical Bureau. 2009. Jumlah Penduduk Miskin di Indonesia. Jakarta: www.bps.go.id. 
Jones, Gareth R. et.al. 2007. Essential of Contemporary Management. New York: The McGraw-Hill Companies.

Kementerian Sosial Republik Indonesia. 2004. Panduan Umum Pengembangan Usaha Ekonomi Produktif Fakir Miskin Melalui Kelompok Usaha Bersama (KUBE) dan Lembaga Keuangan Mikro (LKM). Jakarta: Direktorat Bantuan Sosial Fakir Miskin Direktorat Jenderal Bantuan dan Jaminan Sosial, Kementerian Sosial Republik Indonesia.

Lawrence, Katherine A. 2002. Creativity at Work. San Francisco: A Wiley Company.

Machfoedz, Prof. Dr., MBA. et.al. 2002. Kewirausahaan, Suatu Pendekatan Kontemporer. Yogyakarta: UPP AMP YKPN.

Moser, Caroline O.N. 1993. Gender Planning and Development. Theory, Practice and Training. Canada: Routledge.

Morris, Teresa. 2006. Social Work Research Methods. California: Sage Publication Inc.

Mujiyadi, MSW. 2008. Implementasi Program Pemberdayaan Fakir Miskin melalui Kelompok Usaha Bersama (KUBE). Jakarta: Studi Evaluasi di Delapan Daerah Indonesia

Mutalima, Irene. 2008. Microfinance for Gender Equality: A Dilemma? Christian Enterprise Trust of Zambia. Number 13, (January 2008), International Poverty Centre
Nankervis, Alan Muhammad et.al. 1996. Strategic Human Resource Management. Melbourne: International Thomson Publishing Company.

Ndubisi, Nelson Oly, 2008. Small and Medium Enterprises in the Pacific RIM. Malaysia: KHL. Printing Co. Sdn. Bhd.

Neuman, Lawrence W. 1991. Social Research Method, Qualitative and Quantitative Approaches. New York: Allyn \& Bacon A Viacom Company.

Pemerintah Provinsi Jawa Barat. 2008. Angka Penduduk Miskin di Jawa Barat. Bandung: www.jabarprov.go.id.

Poole, Marshal Scott et.al. 2004. Handbook of Organizational Change and Innovation. New York: Oxford University.

Siegel, Andrew F, \& Morgan, Charles J, 1996. Statistics andData Analysis, An Introduction. Canada:John Wiley \& Sons Inc.

Siti Harti Sastriyani (Editor). 2008, Women in Public Sector. Jogyakarta. PSW UGMTiara Wacana.

Thompson, Leigh et.al. 2006. Creativity and Innovation in Organizational Teams. New Jersey: Lawrence Erlbaum Associates Inc.

Wirasasmita, Yuyun. 2008. Kesalahan Memilih Pola Struktur Model, Makna Hubungan Kausal dalam Model Bisnis/Ekonomi. Bandung: Universitas Pasundan.

World Bank. 2008. Pendidikan Bisnis dan Keterampilan. Jakarta: www.worldbank.orid. 